HEDL-TC-1331

REV. 1

\title{
MATERIALS INTERACTION TEST SUMMARY DESCRIPTION
}

\section{Hanford Engineering Development Laboratory J.C. Krogness}

January 1980 


\section{DISCLAIMER}

This report was prepared as an account of work sponsored by an agency of the United States Government. Neither the United States Government nor any agency Thereof, nor any of their employees, makes any warranty, express or implied, or assumes any legal liability or responsibility for the accuracy, completeness, or usefulness of any information, apparatus, product, or process disclosed, or represents that its use would not infringe privately owned rights. Reference herein to any specific commercial product, process, or service by trade name, trademark, manufacturer, or otherwise does not necessarily constitute or imply its endorsement, recommendation, or favoring by the United States Government or any agency thereof. The views and opinions of authors expressed herein do not necessarily state or reflect those of the United States Government or any agency thereof. 


\section{DISCLAIMER}

Portions of this document may be illegible in electronic image products. Images are produced from the best available original document. 
DAfutley 1/22/80

\section{R.L.Kuewt l/26/80}

R. L. Knecht, Manager

Structural Engineering

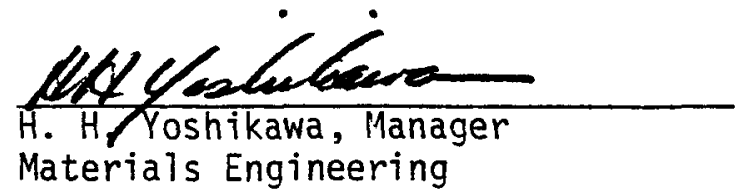




\section{CONTENTS}

Page

FIGURES $\quad v$

I. SUMMARY 1

II. INTRODUCTION 1

III. OBJECTIVES AND SCOPE 2

IV. SUMMARY DESCRIPTION OF EXPERIMENT 2

V. SCHEDULE $\quad$. $\quad 6$

$\begin{array}{ll}\text { VI. FUTURE WORK } & 7\end{array}$

VII. REFERENCES $\quad 8$ 


\section{FIGURES}

Figure

Page

1. MIT Capsule Configuration 4 
MATER IALS INTERACTION TEST SUMMARY DESCRIPTION (189 WKXCAA)

\section{SUMMARY}

The Materials Interaction Test is designed to provide early scoping data on host rock performance and interaction between nuclear waste canister materials and host repository media under conditions representative of expected disposal environments. Capsules containing these materials were put in a spent fuel assembly and subsequently placed in a disposal test to study behavior in a low-level radiation environment at temperatures expected to range between 300 and $400^{\circ} \mathrm{F}$. Thermal control capsules are being exposed in laboratory furnaces to allow a determination and separation of thermal and radiation effects. Posttest specimen examinations are planned to determine material property changes and interaction effects and provide data for understanding the effectiveness of host rock, canister, and cladding materials in longterm waste isolation.

\section{INTRODUCTION}

The Hanford Engineering Development Laboratory (HEDL) is doing material performance studies to develop a fundamental understanding of the behavior of spent fuel under conditions imposed by geologic disposal. The effort is part of the Commercial Waste and Spent Fuel Packaging Program directed by the Office of Nuclear Waste Isolation (ONWI). These studies support Department of Energy (DOE) activities to develop the capability to safely isolate nuclear reactor wastes in geologic repositories. Such isolation depends upon the ability of package, geology, and waste form materials to coexist and maintain their integrity for extended time periods. Tests are necessary to determine the behavior of such materials under geologic disposal conditions not previously investigated. One such test is the Materials Interaction Test (MIT) being conducted by HEDL in conjunction with spent fuel disposal tests. The MIT is a scoping test designed to provide early information to investigate the interaction of candidate spent fuel canister materials 
and geologic storage media at expected disposal temperatures in the presence of low-level neutron and gamma radiation fields. This document provides a summary description of the MIT.

\section{OBJECTIVES AND SCOPE}

The objective of the MIT is to perform scoping tests and obtain interaction information on candidate storage materials and geologies at expected disposal temperatures in gamma and low-level neutron fields.

Scope includes capsule and specimen fabrication, test plan and data package preparation, pre- and post-test examination and analyses, and reporting of results. Information will be obtained relative to canister material corrosion, rock media structural property changes, and chemical transformations that may occur between canister material and rock media during spent fuel disposal. Potential geologic candidates--granite, basalt, argillite, welded tuff, and secondary minerals of basalt and granite--are tested. The materials tested represent fuel cladding types and potential candidates for the spent fuel package canisters. Multiple test samples are contained within test capsules inserted into a spent fuel assembly for drywell emplacement and laboratory thermal tests for control.

\section{SUMMARY DESCRIPTION OF THE EXPERIMENT}

The MIT consists of three groups of test specimens, fabricated from candidate canister materials and geologic samples, which will be used for post-test chemical and mechanical analysis: (1) archives, (2) thermal control, and (3) spent fuel emplacement specimens. A11 specimens have undergone pre-test characterization examination consisting of dimensional and weight measurements. Archive specimens are being retained for chemical and mechanical evaluation in conjunction with the examinations $p l a n n e d$ for emplacement and thermal control specimens to provide reference material data for post-test comparison. Thermal control and emplacement specimens were encapsulated and placed into an electric furnace and spent fuel disposal test, respectively. 
Test specimens for the thermal control and fuel emplacement tests are contained in stainless steel capsules. The fuel emplacement capsules were inserted into two control rod guide tubes of a spent Turkey Point PWR fuel assembly that had been discharged for three years. This spent fuel assembly was subsequently encapsulated and placed in a drywell test at the Engine Maintenance Assembly and Disassembly (EMAD) facility located at the Nevade Test Site (NTS), and is part of the Dry Surface Storage Demonstration (DSSD) program. Companion thermal tests are being performed at HEDL. Temperatures on the drywe 11 test are tracked by the electricaliy heated companion test, to provide a similar thermal history.

Geologic storage media include basalt, granite, argillite, and welded tuff. Canister materials, selected to represent classes of materials, include austenitic and martensite stainless steels, brass, carbon steel, Inconel, and zirconium. Multiple test specimens of geologic media and canister material, organized into groups for specific tests, are encapsulated within seven stainless steel capsules which are attached end-to-end with threaded connectors. Figure 1 shows the MIT capsules and test configuration in an early concept using a single guide tube for emplacement.

Compatibility, chemical transformation, and structural property tests are included. The object of the compatibility test is to assess the interaction between candidate canister metals and surrounding rock in the presence of groundwater (flooded repository) and a dry air atmosphere (dry repository). The compatibility tests are contained in three capsules attached so as to form a test train and installed in a guide tube. Two capsules of this group contain water, to simulate a flooded repository.

Chemical transformation tests are contained in two capsules. These tests assess the effects of thermal and radiation conditions of the repository on the chemical state of repository minerals. Each transformation capsule contains major mineral constituents of basalt and granite. 


\section{MATERIALS INTERACTION TEST}

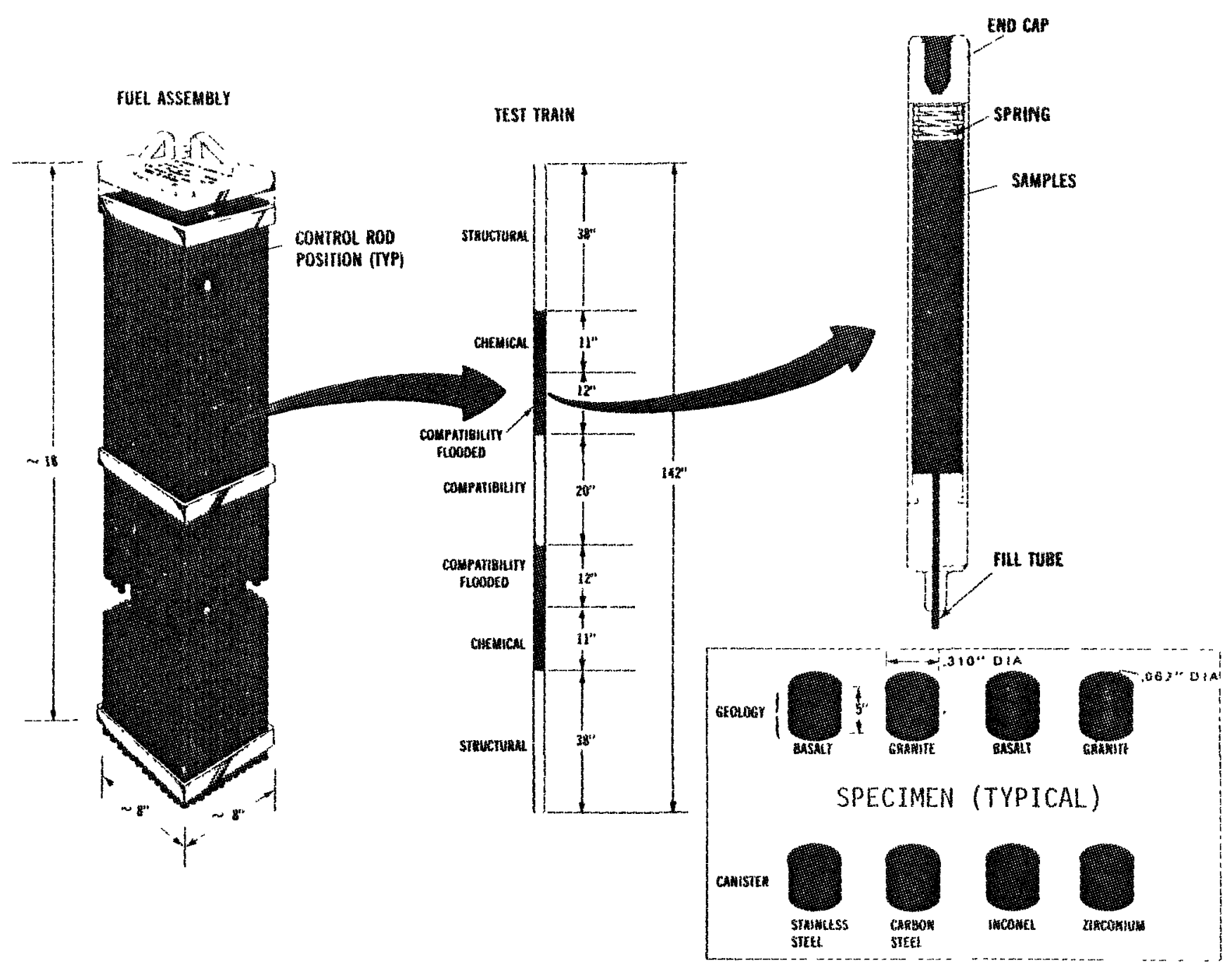

FIGURE 1. MIT Capsule Configuration. 
Structural properties test specimens of granite and basalt are contained in two attached capsules that were installed in a guide tube separate from the compatibility tests. These tests assess the effects of spent-fuel storage on mechanical properties of surrounding geology in the repository.

Details of the MIT capsule design, specimen description, specimen placement, capsule and specimen fabrication, as-built description, and safety analysis are in the data package. (1)

Peak temperatures and neutron fluence in the drywe 11 test will be determined by post-test evaluation of passive instrumentation in the MIT capsules. The passive instrumentation consists of temperature monitors made of low melting point metal alloys, encapsulated in quartz and stainless steel capsules for double containment and placed in three MIT capsules. They cover an active temperature range between 300 and $700^{\circ} \mathrm{F}$. Neutron fluence is measured with solid state track recorder (SSTR) irradiation monitors.

Gamma flux tests were performed on the assembly thimble tube prior to insertion of the MIT test capsules. Active temperature monitoring with thermocouples near the spent fuel packages will provide additional data.

At the completion of the drywell test, the MIT test capsules will be removed from the spent fuel assembly and returned to HEDL for post-test examination. When the companion thermal control test has accumulated an equivalent number of test hours, it will be removed from the test furnace for comparative specimen examination.

In general, the following tests are expected to be included: rock specimens will be mechanically tested for modulus of rupture, (2) fracture toughness, ${ }^{(3)}$ and compressive strength; ${ }^{(4)}$ compatability specimens will be tested for surface-to-surface interaction by metallographic techniques; and rock and mineral samples will be examined for phase structure, grain size, and state of chemical and absorbed water changes. 
Examination techniques are expected to include sections for photomicroscopy, thermal luminescence, $x$-ray diffraction, and thermal gravimetric analysis. Specific examinations to be performed will be determined in detail at a later time.

MIT progress is reported in monthly and quarterly reports submitted to ONWI. Final test results and evaluation will be issued in a test summary at the conclusion of specimen examination.

\section{SCHEDULE}

Major MIT milestones and events are surmarized in the following schedule:

Preliminary Test Design

Obtain geologic test samples

obtain canister test samples

Complete final design

Complete fabrication and assembly of drywe 11 capsule set

Complete fabrication and assembly of companion thermal capsule set

Complete gamma scoping analysis on spent fuel assembly

Ship experiment

Begin drywell irradiation

Begin companion thermal test

End drywe 11 irradiation

Examine test specimens and issue final test report
July 10, 1978

August 15, 1978

August 15, 1978

August 25, 1978

October 13, 1978

December 30, 1978

January 19, 1979

January 1979

January 1979

February 1979

To be determined (3-5 years)

10 to 12 months after test completed 


\section{FUTURE WORK}

Improved understanding of long-term waste disposal effects to package materials and host media requires multiple sample testing. Future experiments similar to the MIT selected canister material and repository samples could provide an expanded data base for predicting the performance of geologic waste isolation.

The Climax Spent Fuel Test ${ }^{(5)}$ planned for NTS in a granite rock mass and the Near Surface Test Facility ${ }^{(6)}$ planned for Hanford in a basalt flow, as well as other currently unspecified disposal tests, provide possible opportunities for additional testing to obtain specific data for understanding material behavior under anticipated disposal conditions. Such tests in conjunction with these planned disposal programs are cost-effective and should be pursued to maximize the studies to develop the capabilities to safely isolate nuclear wastes in geologic repositories. 


\section{REFERENCES}

1. J. C. Krogness, R. B. Davis; Data Package for the Turkey Point Materials Interaction Test CapsuTes, HEDL-TC-1283, Hanford Engineering Development Laboratory, Richland, Washington, January, 1979. Rev.l

2. W. I. Duvall, R. J. Miller, F. O. Wang; Preliminary Report on Physical and Thermal Properties of Basalt, Rockwe 11 Hanford Operations, RHO-BWIC-11, May, 1978, pp. 15.

3. R. A. Schmidt, Fracture Toughness Testing of Rock, Closed Loop, MTS Sys tems Corp. Minneapolis, Minn., November, 1975.

4. "Unconfined Compressive Strength of Intact Rock Core Specimens," ASTM D-2938-71a, Am. Soc. for Testing and Matl's., Philadelphia, 1974.

5. L. D. Ramspott, et al, Technical Concept for Test of Geologic Storage of Spent Reactor Fuel in the Climax Stock, NTS, UCID-18197, May, 1979, Lawrence Livermore Laboratories, Livermore, CA.

6. M. P. Board, W. H. Heneveld, W. D. Martin, and M. P. Hardy; Near Surface Test Facility Phase II Test Plan Project Number B-300b, RHO-BWICD-24, Rockwel1 Hanford Operations, Richland, Washington, November, 1978. 
DISTRIBUTION

Battelle - Columbus Laboratories (4)

JA Carr (3)

RW Klingensmith

DOE - Nevada Test Site (2)

$\mathrm{R}$ Nelson

A Roberts

DOE- RLC (1)

J0 Neff

DOE - RRT-HQ (5)

CR Cooley (2)

CP Gormley

CA Heath

D Vieth

HEDL (21)

DA Cantley

RB Davis

RL Fish

RL Knecht

JC Krogness (2)

ML Nielsen

HH Yoshikawa

Central Files (10)

Publ Service (2)

Doc Management

Lawrence Livermore Laboratory (1)

L Ballou

Westinghouse/AESD

JB Wright

Westinghouse Electric Corp. - Nevada Operations

(1)

DC Durrill 